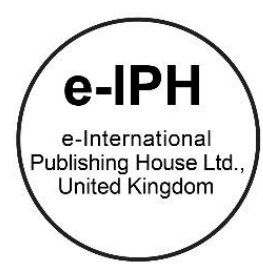

\title{
The Influence of Marine Tourism towards the Quality of Life among Local Tour Operators at Pulau Pangkor, Perak
}

\author{
Firdaus Chek Sulaiman, Ely Rouzee Jamaluddin, Norajlin Jaini, Nur Idzhainee Hashim \\ Centre of Studies for Park and Amenity Management, Faculty of Architecture, Planning and Surveying, \\ Universiti Teknologi Mara, 40450 Shah Alam, Selangor. \\ firdaus_879@yahoo.com \\ Tel: $013-4713320$
}

\begin{abstract}
Marine tourism is one of the main factors contributing to the growth of the tourism sector in Malaysia. Malaysia is among the countries that have the most beautiful islands with diverse marine life. It is attracting visitors to enjoy the beauty of the sea nature. The vibrant activity is an opportunity for local tour operators to engage in the tourism sector. Therefore, the business activities can provide benefits to the local tour operators, but these also have negative impacts on economic, socio-cultural and environment. A preliminary study was conducted to determine tour operator's perceptions about the impact of tourism activities related in entrepreneurial of community in Pulau Pangkor. The study involved 150 respondents who joined the local tour operators in the tourism sector. This study used questionnaire survey as the method of data collection. The findings show the marine tourism involving entrepreneurial activity has a high impact on the socio-economic development of the local population and moderate impact to the environment.
\end{abstract}

Keywords: marine tourism, environmental sustainability, local tour business, local tour operators

eISSN: 2398-4287@ 2017. The Authors. Published for AMER ABRA by e-International Publishing House, Ltd., UK. This is an open access article under the CC BYNCND license (http://creativecommons.org/licenses/by-nc-nd/4.0/). Peer-review under responsibility of AMER (Association of Malaysian Environment-Behaviour Researchers), ABRA (Association of Behavioural Researchers on Asians) and cE-Bs (Centre for Environment-Behaviour Studies), Faculty of Architecture, Planning \& Surveying, Universiti Teknologi MARA, Malaysia.

https://doi.org/10.21834/e-bpj.v2i6.1000

\subsection{Introduction}

The tourism industry is the largest and the fastest growing sector of economy in the world over the past six decades (World Tourism Organization, 2014). In Malaysia, the development of the tourism industry also experienced growth from year to year. In 2013 , Malaysia recorded a third place in the list of countries receiving the highest international tourist arrivals in the Asia-Pacific region, which accounted for 25.7 million people (World Tourism Organization, 2014). The growth of this industry brings impact towards the economic, socio-cultural and environment.

Marine tourism is one of the leading contributor to the growth of the tourism sector in Malaysia and is gradually growing. It is a special form of tourism where tourist decides to spend most of their vacation time on the marine activities. It attracts visitors to explore and enjoy the beautiful views of the sea. Development and planning should be designed not only to attract tourists but also benefit for the economic growth among the local tour operators. The travel industry had produced local products such as arts and crafts, recreation, employment, transport, and accommodation. Today, many countries are competing to develop their marine tourist area.

The study is to measure the impacts of marine tourism activities to local tour operator's development at Pulau Pangkor and to identify the types of local tour business involved in marine tourism at Pulau Pangkor. This study measures the involvement of the local

eISSN: 2398-4287C 2017. The Authors. Published for AMER ABRA by e-International Publishing House, Ltd., UK. This is an open access article under the CC BYNCND license (http://creativecommons.org/licenses/by-nc-nd/4.0/). Peer-review under responsibility of AMER (Association of Malaysian Environment-Behaviour Researchers), ABRA (Association of Behavioural Researchers on Asians) and cE-Bs (Centre for Environment-Behaviour Studies), Faculty of Architecture, Planning \& Surveying, Universiti Teknologi MARA, Malaysia.

https://doi.org/10.21834/e-bpj.v2i6.1000 
tour operators in the marine tourism, and types of business activities carried out. The goal is to identify the impact of tourism activities run by local tour operators on the development of local communities at Pulau Pangkor.

The involvement of local tour operators in Pulau Pangkor are important towards the tourism industry which played a crucial role in facilitation in the community development through business mentoring and educational opportunities. The process of tourism development is important towards the community which contributes in increasing skill, knowledge and improving the community's economy level.

Based on the situation in Pulau Pangkor, some issues occurred could undermine the development of the tourism industry. The involvement of the local tour operators in the success of tourism activities should be planned as soon as possible to avoid the things that can prevent, hinder and further damage the development of the industry. Elements such as the involvement and engagement effects need to be identified to ensure the success of the business. Selection of Teluk Nipah and Pasir Bogak is due to the evidence of the involvement of local tour operators in marine tourism industry which could be an impact towards the social, economy and environment as well.

\subsection{Study area}

This research was conducted in Pulau Pangkor focusing in Teluk Nipah and Pasir Bogak. It has been chosen as a survey location because since it had become a tourism destination that has involvement from the local tour operators to be the local tour business operator. According to Local Plan of Pulau Pangkor (1999-2015), the number of houses studied was 1565 units and inhabited by 6260 people whereas Manjung City Council (2013), indicated the total number of tourist to Pulau Pangkor were 84,720 or $34 \%$ for local tourist between the year of 2004 to 2007 . While the foreign tourist recorded of 32,086 or $14 \%$ for the same period.

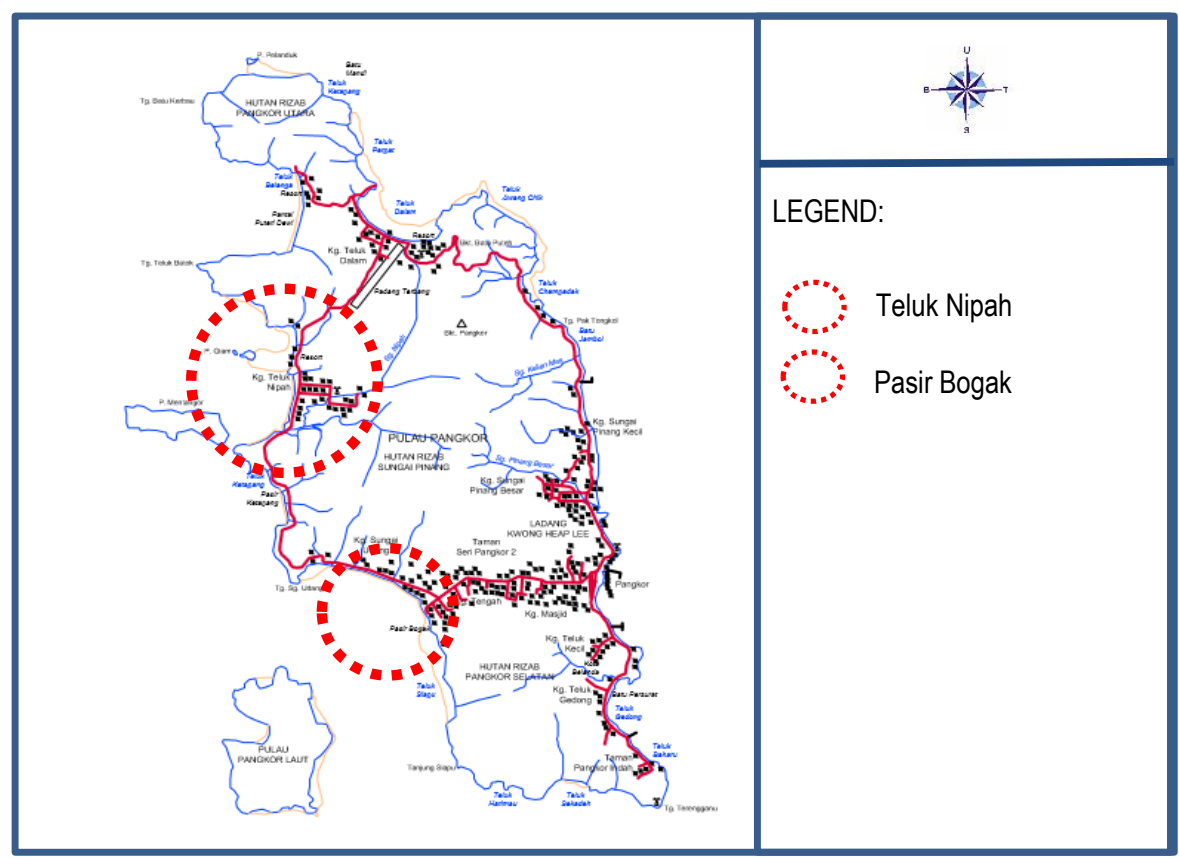

Fig. 1: Map of Pulau Pangkor, Perak

\subsection{Literature Review}

\subsection{Marine Tourism}

According to Orams, M. B. (2002), marine and coastal tourism involving travel of one's place of residence and had cause affected to the marine. However, Mohonk Agreement, (2001), described the marine tourism is closely related to sustainable tourism, which aims to reduce the logical impact and socio-cultural as well as providing economic benefits to local communities and host countries. Sustainable development is to meet the needs of the present generation without compromising the ability of future generations to respond to their needs. The concept of tourism can be analysed by considering some of the published descriptions and definitions. "Tourism has a connotation of leisure travel and tends to be synonymous with holidays (vacations). This is also reflected in dictionaries, which commonly refer to tourism as travel for pleasure business usage, the language of those who earn their living from serving tourists; most of them see tourism regarding the products they sell and the markets they serve"(Medlik, 2003). This statement shows that tourism is a product which has a major impact on community life hence, the local tour operator's products must obtain a welcome tourist spot for profit. 
The involvement of the community is an integral part of a tourism development. It is important that every member of the community involved in the tourism development activities not only it contributes to the development of tourism destinations in fact, indirect benefits to the local tour operator's members. According to studies on 'The Impact of Tourism on Small Business Performance: Empirical Evidence from Malaysian Islands' by Pazim Othman and M. Mohd Rosli (2011), stated that Teluk Nipah, Coral Bay, and Pasir Bogak are some of the most attractive beaches available on the island. Tourism academics have explored in detail the involvement of residents in tourism development. This was because the local population is one of the stakeholders who play a major role in tourism development.

Marine based tourism businesses include ferry companies, marinas, cruise lines, and other form of water transportation. Therefore, transport services in Pulau Pangkor also involved in the tourism industry which bring tourist to move from one to another place. On the other hands, marine facilities included equipment of water sport activities. Other services in marine tourism mainly in Pulau Pangkor are retail and handicraft, food services and accommodation.

\subsection{Community Development}

In understanding the meaning of community development, the study needs first to be clear about the term of "community" itself. The definition of community is highly problematic, and there are many definitions (Tesoriero \& Lfe, 2006). For most tourism purposes, the concept of the community often hinged upon a common location. However, it has also been used to refer to groups that are not geographically determined but share common characteristics or interests. For assessing the level of tourism development, a community can be any existing or potential network of individuals, groups and organisations that share or can share common concerns, interest, and goals (Bush et al., 2002). The concept of community development is explored regarding participation, empowerment, and community capacity as they related to tourism development (Singh, Timothy, \& Dowling, 2003). Community development can be seen as building social capital for collective benefits which uses skill and knowledge and strategy in their practice (Gilchrist, 2004).

Community development aims to increase citizens' participation in their community. In community development, the emphasis is placed on the community as a social system, bounded by geographical location or common interest (Talbot \& Verrinder, 2005). Community development is linked to community capacity building through a shared focus on building capacity to a collective, participatory force (Williams, 2004). Community development is viewed as the best way to build the capacity of community residents to engage with each other and find solutions to issues that affect their community. Community development holds potential to build community cohesion by facilitating a community's capacity to engage connections between individuals, organisations and groups (Chaskin et al., 2001). Helping a community to build its capacity for development is a primary goal of community development (Ife, 2002). Community development is a process that allows community residents to come together to plan, generate solutions and take action developing the evolution of social, economic, environmental and cultural aspects of the community (Hackett, 2004). Community development emphasizes the importance of participation as a means of strengthening local communities (Kuponiyi, 2008).

Tourism is increasingly seen as a key community tool, with the recognition of its economic contribution in bolstering stagnating economies and its ability to unify local tour operator's residents (Fennell, 2003). At community levels, tourism offered opportunities for direct, indirect, and induced employment and income, spurring regional and local economic development (Aref, 2010; Coccossis, 2004). According to Nor Aini Haji Idris (2008), stated that poverty can occurred due to working with low income, a high number of dependents, and unemployed. Tourism may have many different effects on the social and cultural aspects of life in a region or area, depending on the cultural and religious strengths of that region. The interaction between tourists and the host community can be one of the factors that may affect a community as tourists may not be sensitive to local customs, traditions, and standards. The effect can be positive or negative in the host community (Mathieson \& Wall, 1982). According to Oliver (2001), economy provides opportunities for every individual to improve the sustainability of their lives such as getting a better job, improve life status and so on. Income enables individuals to various types of expenses self and family.

\subsection{Result and discussion}

\subsection{Background of Respondents}

The highest category of respondents was between the range of 18 to 25 years old which were 40 respondents (26.7\%). Followed by 26 to 30 years old with 30 respondents (20\%). The lowest categories were 36 to 40 years old with 22 respondents (14.7\%). This shows that in this research, more young people engage in marine tourism and provide services to tourists. The gender data shows two categories which are male and female with 92 respondents $(61.3 \%)$ and 58 respondents $(38.7 \%)$ respectively. Therefore, the results indicate that more male than female which is local tour operator involved in marine tourism activities in Pulau Pangkor. According to Lucy Ferguson (2006), in her research about 'Analysing the Gender Dimensions of Tourism' state that how male control over household income had been diminished by many opportunities for women to earn money in tourism communities. Marital status data is also recorded in the survey data. The highest category is married with 89 respondents $(59.3 \%)$, while single status with 60 respondents equals to $(40.0 \%)$. The other items such divorce is only one person of the respondent with $(0.7 \%)$.

Another item that been recorded is in the occupation of respondents at Pulau Pangkor. Among the highest occupation is selfemployment which is 124 respondents with $82.7 \%$. Followed by the private sector were by 19 respondent's equals to $12.7 \%$. Moreover, the lowest is government personnel were seven respondents with $4.7 \%$. In this study present that majority local operators who engage in self-employment and only focus on the tourism sector in Pulau Pangkor. Regarding the income of respondent, the 
highest income is RM1,001 to RM2,000 were 62 respondents (41.3\%). The intermediate category is below RM 1000 were record 60 respondents with $40 \%$, and RM2,001 to RM3,000 is 18 to $12 \%$. Moreover, lastly, the lowest category is RM 4001 and above by two respondents only by $1.3 \%$. According to the respondents, they could sustain this kind of income because the cost of living in rural areas that are not too high in Pulau Pangkor.

The race of the visitors shown that the highest was Malay, about 112 respondents or $74.7 \%$. Next item is Chinese; about 24 respondents are recorded or $16 \%$. The lowest race was Indian, about 14 respondents, $9.3 \%$. This means that more Malay engaged in marine tourism where these communities need to make a living other than fisheries. The highest rate that has been recorded for the research is secondary level with 86 respondents (57.3\%). The second largest is primary level was about 30 respondents $(20 \%)$. The college and university graduated recorded 16 respondents with $10.7 \%$. The lowest is the small group for other item was recorded in this section; others define that they do not have any education level, about two respondents or $1.3 \%$. Yep White (1985) stating that the academic qualifications and technical not a key requirement to become entrepreneurs.

\subsection{Analysis for Tour Operator Information}

Table 1 shows the result of tour operator information. Based on the result, indicated the division of the length of business. The highest period of business was less than five years which is 53 respondents (35.3\%). For the duration of business between 10-14 years and 16-19 years indicated 21 respondents (14\%) for each duration, only 17 respondents $(11.4 \%)$ were involved for $20-25$ years in tour business. Based on the table, the highest of business types is retail and handicraft with 40 respondents with (26.7\%). Second highest is accommodation with 36 respondents (24\%) followed by transportation activities with 30 respondents (20\%) and marine facilities tour with 24 respondents $(16 \%)$ respectively. Overall food services indicated the lowest types of business with 20 respondents (13.3\%).

Table 1: Data of Tour Operator Information

\begin{tabular}{lcc}
\hline Age of Business & Frequency & Percentage $(\%)$ \\
\hline $20-25$ years & 17 & 11.4 \\
$15-19$ years & 21 & 14.0 \\
$10-14$ years & 21 & 14.0 \\
Less than 5 years & 53 & 35.3 \\
Total & 150 & 100 \\
\hline Types of services & & \\
\hline Accommodation & 36 & 24 \\
Food service & 20 & 13.3 \\
Transportation & 30 & 20 \\
Retail and handicraft & 40 & 26.7 \\
Marine water sport & 24 & 16 \\
Total & 150 & 100 \\
\hline
\end{tabular}

\subsection{Analysis for business details of local tour operator}

Table 2 represented the types of local business in Pulau Pangkor which further details types of business services stated in Table 1. The item under types of business was conducted by local tour operator at Pulau Pangkor. The types of local business have five activities which are accommodation, retail and handicraft, transportation, marine facilities tour, and food services. The following Table 2 shows the types of business, but it lists the details of each type of activities.

First service was accommodation which has four items including hotel, resort and chalet, homestay, and others. Among this category, resort and chalet were the highest involved by the respondents with 21 respondents (14\%). This result proved that resort and chalet help in generating income to tour operators which involved them through the management, services, housekeeping, and others. It is believed that tour operators were more likely to join in resort and chalet since it's the highest demand from the tourist. Resort and chalet also offer an affordable rate and provide good ambiance that had attracted more visitors and tourist.

In food services, majority of respondents involved in food stall business where it stated 11 respondents with (7.3\%). Local tour operator provides more food in food stall compared to the restaurant because local authorities allow the majority placement food stall. Furthermore, the local tour operators were interested to start business in small-medium enterprise.

The following services were transportation where the taxi services were the most involved by the respondents with (12\%) 18 respondents. In Pulau Pangkor, most of the visitors left their transport in mainland. As such, the taxi services become the main transportation among the tourist.

Based on table 1, retail and handicraft were the major services that has the highest involvement among the respondents. From the data in Table 2, there were three items in this service. Among the three items, soft retail such as towel, clothes and fabric were the most involvement by the respondent with 16 respondents (10\%). Finally, the service of marine water sport indicated 13 respondents $(8.7 \%)$ involved in water recreation activities, while 10 respondents $(6.7 \%)$ were on water sports rental equipment. Overall, resort and chalet $(14 \%)$, taxi services $(12 \%)$ and soft goods retail $(10.7 \%)$ were the top three among the highest services involved by the respondents. 
Table 2: Types of local business at Pulau Pangkor

\begin{tabular}{llcc}
\hline Elements & Item & Frequency & Percentage (\%) \\
\hline Accommodation & Hotel & 12 & 8 \\
& Resort and chalet & 21 & 14 \\
& Homestay & 3 & 2 \\
Food Services & Others & 1 & 0.7 \\
& Restaurant & 9 & 6 \\
Transportation & Food stall & 11 & 7.3 \\
& Taxi services & 18 & 12 \\
& Car and motorcycle rental & 9 & 6 \\
Retail and handicraft & Ferry and boat & 4 & 2.7 \\
& Specialist retail & 12 & 8 \\
& Soft goods retail & 16 & 10.7 \\
Marine water sport & Seafood product & 11 & 7.3 \\
& Water sport rental equipment & 10 & 6.7 \\
& Water recreation activities & 13 & 8.7 \\
& & 150 & 100 \\
\hline
\end{tabular}

\subsection{Analysis for socio-cultural impact}

Table 3 shows the result of the influence of marine tourism towards the social impact. Based on the table, there were five influences which comprised of foreign culture, better facilities, crime and social problems, community development, and English proficiency.

The result indicated English proficiency had mostly influenced the social community. The mean 4.03 which mostly indicated agreed by the respondents. It is believed that the community has improved their English proficiency through the communication with foreign tourists. This had influenced the community to train themselves speaking in English. According to Sahazali, N., \& Choy, E. A. (2013) stated the social impact resulting from ecotourism activities in Seri Manjung analysis found an increased impact on the use of English. The arrival of foreign tourists has been able to improve English proficiency among the locals. Therefore, they need to learn to communicate in English language to improve among the tourist.

On the other hands, the other four elements were on the neutral scale. However, the three aspects (better facilities, crime and social problem, community development) shows the mean that inclined to be (Agreed) is between 3.50-3.99. Whereas, only the elements on foreign culture obtained the least mean (3.35) and slightly tend to be (Disagreed).

Table 3: Social impact

\begin{tabular}{|c|c|c|c|c|c|c|c|c|c|c|c|}
\hline \multirow[t]{2}{*}{ Elements } & \multicolumn{2}{|c|}{$\begin{array}{l}\text { Strongly } \\
\text { Disagree }\end{array}$} & \multicolumn{2}{|c|}{ Disagree } & \multicolumn{2}{|c|}{ Neutral } & \multicolumn{2}{|c|}{ Agree } & \multicolumn{2}{|c|}{ Strongly agree } & \multirow[t]{2}{*}{ Mean } \\
\hline & Freq & $\%$ & Freq & $\%$ & Freq & $\%$ & Freq & $\%$ & Freq & $\%$ & \\
\hline Foreign Cultures & 7 & 4.7 & 12 & 8.0 & 67 & 44.7 & 54 & 33.3 & 14 & 9.3 & 3.35 \\
\hline Better Facilities & 6 & 4.0 & 13 & 8.7 & 39 & 26.0 & 67 & 44.7 & 25 & 16.7 & 3.61 \\
\hline $\begin{array}{l}\text { Crime and Social } \\
\text { Problems }\end{array}$ & 3 & 2.0 & 10 & 6.7 & 50 & 33.3 & 55 & 36.7 & 32 & 21.3 & 3.69 \\
\hline $\begin{array}{l}\text { Community's } \\
\text { Development }\end{array}$ & 6 & 4.0 & 1 & 0.7 & 31 & 20.7 & 88 & 58.7 & 24 & 16.0 & 3.82 \\
\hline $\begin{array}{l}\text { Increase English } \\
\text { proficiency }\end{array}$ & 7 & 4.7 & 1 & 0.7 & 20 & 13.3 & 74 & 49.3 & 48 & 32.0 & 4.03 \\
\hline
\end{tabular}

\subsection{Analysis for economic impact}

Table 4 shows the statement on how the marine tourism influenced the economic impact. Based on the result, there were four elements included in economic impact. All four elements (job opportunities to local communities, increase the living standard, increase incomes, and decrease unemployment rate) obtained slightly similar mean which is in the range from 3.78 to 3.99 (Neutral). These indicated that the economic impact was not strongly influenced the local tour operators. There were none of the elements attained mean more than 4.00 (Agree). However, all the mean for each item gained mean more than 3.50 which is tended to be Agree. It is believed that if there is some improvement on the economic opportunities, it will improve their economic impact. In general, tourism is generating the income to local tour development. Local tour operators at Pulau Pangkor also contribute to marine tourism activities and increase the income indirectly through the arrival of tourist. Based on David J. Telfer, Richard Sharpley, (2008), the most significant economic benefit among the local levels is income generation. Tourism provides an income for any individual or business 
that provides goods or services for tourists. This includes hotels, restaurants, bars, transport, and entertainment. All the owners and employees of these businesses gain directly from the tourism industry.

Table 4: Economic impact

\begin{tabular}{|c|c|c|c|c|c|c|c|c|c|c|c|}
\hline \multirow[t]{2}{*}{ Elements } & \multicolumn{2}{|c|}{$\begin{array}{l}\text { Strongly } \\
\text { Disagree }\end{array}$} & \multicolumn{2}{|c|}{ Disagree } & \multicolumn{2}{|c|}{ Neutral } & \multicolumn{2}{|c|}{ Agree } & \multicolumn{2}{|c|}{ Strongly agree } & \multirow[t]{2}{*}{ Mean } \\
\hline & Freq & $\%$ & Freq & $\%$ & Freq & $\%$ & Freq & $\%$ & Freq & $\%$ & \\
\hline $\begin{array}{l}\text { Job Opportunities to } \\
\text { Local Communities }\end{array}$ & 8 & 5.3 & 2 & 1.3 & 27 & 18.0 & 80 & 53.3 & 33 & 22.0 & 385 \\
\hline $\begin{array}{l}\text { Increase the Living } \\
\text { Standard }\end{array}$ & 10 & 6.7 & 2 & .3 & 34 & 22.7 & 69 & 46.0 & 35 & 23.3 & 3.78 \\
\hline Increase Incomes & 3 & 2.0 & 3 & 2.0 & 36 & 24.0 & 58 & 38.7 & 50 & 33.3 & 3.99 \\
\hline Rate & 4.0 & 1 & 0.7 & 42 & 28.0 & 68 & 45.3 & 33 & 22.0 & 3.81 & \\
\hline
\end{tabular}

\subsection{Analysis for Environment Impacts}

Table 5 shows on the influenced of marine tourism towards environmental impact. The elements of environmental impact include pollution, maintenance of infrastructure and traffic congestions. The traffic congestion shows the highest mean 4.15 gained in environmental impact. The arrival of tourists especially on weekends resulted in the area crowded and dense. Many respondents suggested that the government expand the roads in Pulau Pangkor due to small and narrow roads. According to JA Ibrahim, N Abdul Razak, MZ Ahmad (2012), stated that the layout of the buildings that unorganized and had created an uncomfortable environment and congestion, especially along the coastline. Tourist forced through the narrow spaces between buildings to get to the beach. On the other hands, pollution and maintenance of infrastructure indicated the mean 3.63 and 3.93 respectively fall on the neutral scale. However, the mean was inclined to be (Agree) which need some improvement on these matters.

Table 5: Environmental impact

\begin{tabular}{|c|c|c|c|c|c|c|c|c|c|c|c|}
\hline \multirow{2}{*}{ Elements } & \multicolumn{2}{|c|}{ Strongly Disagree } & \multicolumn{2}{|c|}{ Disagree } & \multicolumn{2}{c|}{ Neutral } & \multicolumn{3}{c|}{ Agree } & \multicolumn{3}{c|}{ Strongly agree } & Mean \\
\cline { 2 - 12 } & Freq & $\%$ & Freq & $\%$ & Freq & $\%$ & Freq & $\%$ & Freq & $\%$ & \\
\hline Pollution & 4 & 2.7 & 9 & 6.0 & 48 & 32.0 & 67 & 44.7 & 22 & 14.7 & 3.63 \\
\hline $\begin{array}{c}\text { Maintenance of } \\
\text { Infrastructure }\end{array}$ & 1 & 0.7 & 6 & 4.0 & 30 & 20.0 & 79 & 52.7 & 34 & 22.7 & 3.93 \\
\hline Traffic Congestion & 1 & 0.7 & 7 & 4.7 & 17 & 11.3 & 69 & 46.0 & 56 & 37.3 & 4.15 \\
\hline
\end{tabular}

\subsection{Conclusion}

Overall, the study found that marine tourism activities in Pulau Pangkor have influenced on the social, economic and environment. The industry had supported the government in improving the growth of the economy. Regarding economic impacts have been identified marine tourism increased revenue to the local tour operators. Many initiatives that could be done by local people in promoting marine tourism in Pulau Pangkor. Meanwhile, the local tour operators proved that there were influenced on sociocultural, but the impact was at a minimum level. Sociocultural effects are as positive can improve English language skills while shaping their culture.

On the other hand, the negative impact regarding environmental and social as even more marked. Locals feel that marine tourism conducted a little positive impact regarding economic and sociocultural but more negative influence, particularly regarding the environment. There is still a lot more jobs and business opportunities that should be open to local communities to improve their economies. Similarly, another effort is to provide facilities and services to enhance the quality of the marine tourism product. Pulau Pangkor development will be improved and maintain as a destination attraction if the locals banded together to keep around and identify the impact that comes from the marine tourism.

\section{Acknowledgements}

We would like to thank the Centre of Studies Parks and Amenity Management, Faculty of Architecture, Planning and Surveying, UiTM Shah Alam, Selangor, Malaysia, Syazwana binti Jamaludin who had contributed in the data collection and all the respondents who kindly participated in the questionnaires survey. 


\section{References}

Aref, F. (2010). Residents' Attitudes towards Tourism Impacts: A Case Study of Shiraz, Iran. Tourism Analysis, 15(2), 253-261

Bush, R., Dower, J., \& Mutch, A. (2002). Community capacity index manual. Queensland: Centre for Primary Health Care, The University of Queensland

Chaskin, R. J., Brown, P., Venkatesh, S., \& Vidal, A. (2001). Building Community Capacity. New York: Aline De Gruyter

David J. Telfer, Richard Sharpley, (2008). Tourism and Development in the Developing World. Routledge, ISBN: 9780415371445

Eshliki, S. A., \& Kaboudi, M. (2012). Perception of Community in Tourism Impacts and their Participation in Tourism Planning : Ramsar, Iran. Journal of Asian Behavioural Studies, 2, 51-64.

Fennell, D. A. (2003). Ecotourism: an introduction (2 ed.): Routledge, UK.

Gill, S. (2010). Tourism Development in Local Communities : As a Community Development Approach. Journal of American Science, 6(2), 155-161.

Hackett, H. (2004). Community capacity building. Paper presented at the conference of social assistance professionals in the provincial and municipal sectors. Retrieved 29, May, 2009, from http://www.ranaprocess.com/Articles/Arti cles/Community\%20Capacity\%20Buildin g.pdf

Ife, J. (2002). Community development: Community- based alternatives in an age of globalisation. Sydney: Longman Press.

JA Ibrahim, N Abdul Razak, MZ Ahmad (2012). The impact of tourism development on beach destination: Case study of Cenang Beach, Langkawi. Persidangan Kebangsaan Ekonomi Ke VII, 601-610. Retrieved from: www.ukm.my/fep/perkem/pdf/perkemVII/PKEM2012_2E2.pdf

Kaur, C. R. (2007). Ecotourism in Malaysia's Marine Parks: Principles, Issues and the Effects of "Green Washing" Practices. 5th Asia Pacific Ecotourism Conference 2007 (APeco 2007),2007(October).Keusahawanan, T. A., \& Sekitar, A. (2012). Jurnal Teknologi Full paper Pelancongan Marin : Impak Aktiviti Selam Skuba dan Snorkeling, 59, 57-63.

Koens, J. F., Dieperink, C., \& Miranda, M. (2009). Ecotourism as a development strategy: Experiences from Costa Rica. Environment, Development and Sustainability, 11, 1225- 1237. http://doi.org/10.1007/s10668-009-9214-3

Kuponiyi, F. A. (2008). Community Power Structure: The Role of Local Leaders in Community Development Decision Making in Ajaawa, Oyo State, Nigeria. The Anthropologist, 10(4), 239-243.

Manaf, A., Saad, S., \& Hussain, M. Y. (2012). Isu keterancaman keselamatan perairan Mersing dan pulau-pulau di sekitarnya, 6(6), 49-58.

Mathieson, A. \& Wall, G. (1982), "Tourism: economic, physical and social impacts", Longman: Harlow, UK.

Medlik, 2003. Dictionary of Travel, Tourism and Hospitality. Butterworth-Heinemann, UK, ISBN: 0750656506

Mohammadi, M. (2010). Local People Perceptions toward Social, Economic and Environmental Impacts of Tourism in Kermanshah (Iran). Social Science, 6(11), 220225 .

Mohd, A., Ak, R., Suki, N. M., \& Dawood, M. M. (2014). Activity and Support Factors Influencing Increased Value Of Invertebrates In Ecotourism, $72-75$.

Nguyen, Q.-H. (2007). Putting Community First: Tourism for Development in Doi Village, Central Vietnam. School of Social Science, Master of (November).

Orams, M. B. (2002). Marine ecotourism as a potential agent for sustainable development in Kaikoura, New Zealand. International Journal of Sustainable Development, 5(3), 338. http://doi.org/10.1504/IJSD.2002.003757

Othman, N., Mohamed, S., \& Aziz, F. K. (2012). Tourism activities and its impact on environmental sustainability in coastal areas. International Business Management, 6(6), 629-633. http://doi.org/10.3923/ibm.2012.629.633

Pakhriazad, H. ., Mohd. Hasmadi, I., Aida, H. M. ., \& Jusoff, K. (2014). Historical and Current Legislations of Taman Negara National Park Peninsular Malaysia. Journal of Politics and Law, 2(1), 44-49. http://doi.org/10.5539/jpl.v2n1p44

Pazim Othman and M. Mohd Rosli (2011) The Impact of Tourism on Small Business Performance: Empirical Evidence from Malaysian Islands, International Journal of Business and Social Science. Vol. 2 No. 1. Pages 11-21. Retrieved from: http://www.jjbssnet.com/journals/Vol._2_No._1\%3B_January_2011/2.pdf.

Phimmakong, K. (2011). Local perspective on Community Based Ecotourism : A Case Study in Ban Na in Phu Khao Khoay National Protected Area, Lao PDR. Projek, L., \& Kumpulan, I. (2013). Laporan projek inovasi kumpulan kaizen 2013, (2030). Rahayu, I. (2014). Tourism Sea Activities that Cause Damages Towards Coral Reefs in Sembilan Islands, 1(April 2013), 22-24.

Ross, S., \& Wall, G. (1999). Ecotourism: Towards congruence between theory and practice. Tourism Management, 20(1), 123-132. http://doi.org/10.1016/S0261-5177 (98)00098-3

Sahazali, N., \& Choy, E. A. (2013). Ekopelancongan di Taman Paya Bakau, Seri Manjung , Perak : Persepsi penduduk terhadap impak pembangunan Development impact of Malaysian ecotourism as perceived by the local public : The case of Bakau, Seri Manjung, Perak, 3(3), 69-79.

Singh, S., Timothy, D. J., \& Dowling, R. K. (Eds.). (2003). Tourism in destination communities. Cambridge, USA: CABI publishing

Talbot, L., \& Verrinder, G. (2005). Promoting Health: The Primary Health Care Approach (3 ed.): Elsevier, Churchill Livingstone, Australia. Gilchrist, A. (2004). The wellconnected community: a networking approach to community development: Community Development Foundation (Great Britain), The Policy Press, UK 
Tesoriero, F., \& Lfe, J. (2006). Community development: community -based alternatives in an age of globalisation: Pearson Education Australia

Toro, B., \& Claiborne, P. (2010). Community Participation in Tourism Development and the Value of Social Capital Master of Science in Tourism and Hospitality Management Master

Tranel, M. J. (2000). Wilderness Management Planning in an Alaskan National Park : Last Chance to Do It Right? Wilderness, 5

United Nations. (2002). Sustainable Tourism, Environmental Protection and Natural Resource Management: Paradise on Earth? Growth, (February), 20 -22.

Vuuren, C. Van, \& Slabbert, E. (2011). Travel Motivation and Behaviour of Tourists to a South African Resort. International Conference on Tourism and Management StudiesAlgarve 2011, I, 295-304. http://doi.org/http://tmstudies.net/index.php/ectms/article/view/196

Wang, H. (2009). Study on the Eco-tourism Environment Protection Based on the External Theory, 13-17.

Williams, C. C. (2004). Community Capacity Building: A Critical Evaluation of the Third Sector Approach. Review of Policy Research, 21(5), 729-733.

Zaei, M. E., \& Zaei, M. E. (2013). The Impacts of Tourism Industry on Host Community. European Journal of Tourism Hospitality and Research, 1(2) 